\title{
DOI: http://dx.doi.org/10.35137/jabk.v6i3.322 \\ PENGARUH EVALUASI PENGENDALIAN INTERNAL DAN PENERAPAN DUE PROFESSIONAL CARE TERHADAP KUALITAS AUDIT
}

\author{
Jeane Widianingsi ${ }^{1}$ \\ Program Studi Akuntasi Fakultas Ekonomi \\ Universitas Krisnadwipayana \\ Budi Tri Rahardjo ${ }^{2}$ \\ Program Studi Akuntasi Fakultas Ekonomi \\ Universitas Krisnadwipayana \\ buditrirahardjo@yahoo.com
}

\begin{abstract}
This research conducted with the aim of testing the extent of the evaluation of internal control and the application of due professional care to audit quality in KAP Ispiady \& Dande. This research uses quantitative analysis. In this study, researchers used primary data by distributing questionnaires to KAP Ispiady \& Dande employees. Then the data analyzed using multiple linear regression analysis with the help of the statistical package for Social Sciences (SPSS) version 22. The results showed that the internal control variable and the due professional care variable had a significant influence on audit quality and the results showed that the two independent variables jointly have a significant influence on audit quality.
\end{abstract}

\section{Keywords: Internal Control, Due Professional Care and Audit Quality}

\section{PENDAHULUAN}

Audit merupakan proses yang sistematik dan independen untuk memperoleh bukti audit dan mengevaluasinya secara objektif guna menentukan sampai sejauh mana kriteria audit dipenuhi. Hasil dari audit selain dipergunakan untuk perusahaan, dapat digunakan oleh organisasi luar untuk menilai perusahaan tersebut. Di Indonesia telah memberikan kewajiban kepada perusahaan untuk melaporkan laporan keuangan yang sudah di audit oleh KAP. Adanya kewajiban tersebut menjadikan kebutuhan jasa auditor di Indonesia menjadi meningkat. Terlihat dari banyaknya jumlah KAP di Indonesia, sehingga semakin banyak pilihan bagi perusahaan untuk menetukan KAP yang akan mengaudit laporan keuangan perusahaan.

Dari pertimbanagan perusahaan menentukan KAP tersebut, KAP harus memberikan kualitas audit yang baik dan mampu menangani resiko. Resiko yang sering terjadi seperti kegagalan bisnis yang akhirnya dihubungkan dengan kegagalan auditor dan mempengaruhi persepsi masyarakat pemakai laporan keuangan atas kualitas audit. Resiko tersebut dapat mengancam kualitas audit yang dihasilkan oleh KAP, sehingga auditor dituntut untuk memiliki sikap profesional dan rasa bertanggung jawab selama melaksakan tugas audit.

Dari beberapa faktor yang memiliki pengaruh pada kualitas audit, peneliti menentukan evaluasi pengendalian internal yang diterapkan KAP menjadi bagian pengamatan bagi peneliti guna menilai apakah evaluasi pengendalian internal sudah dilakukan dengan benar. Pentingnya mengevaluasi pengendalian internal KAP sebelum melaksanakan pemeriksaan, karena hal ini akan berdampak pada pendapat atau opini atas suatu laporan keuangan yang dihasilkan.

Selanjutnya peneliti menetapkan penerapan due professional care pada auditor menjadi bagian yang perlu dilakukan dalam melaksanakan tugasnya. Memiliki sikap skeptisme profesional guna mengurangi kecurangan, salah saji matrial, sikap kritis selama menjalankan tugas, sehingga penerapan due professional care yang dijalankan sudah sesuai dengan peraturan yang berlaku dan klien tidak menajadi korban auditor yang tidak memiliki etika profesi.

Peneliti memilih faktor pengendalian internal dan due professional care pada 
penelitian ini, karena faktor tersebut dibutuhkan dalam melaksanakan tugas KAP. Beberapa penelitian sebelumnya yang membahas mengenai due professional care telah dilakukan oleh Pupatriani (2014) Universitas Pasundan yang berjudul Pengaruh Independensi dan Due Profesional Care Terhadap Kualitas Audit (Survei pada Kantor Akuntan Publik di Bandung). Pupatriani (2014) menjelaskan variabel due professional care memiliki pengaruh pada kualitas audit. Selanjutnya penelitian sebelumnya yang membahas pengendalian internal telah dilakukan oleh Gaffar (2015) Universitas Hasanudin dengan judul Pengaruh Tingkat Pemahaman Pengendalian internal Terhadap kualitas Audt (Survei pada KAP di Makasar). Gaffar (2015) menjelaskan tingkat pemahaman pengendalian internal yang terdiri dari aktivitas pengendalian, penilaian risiko, lingkungan pengendalian, pemantauan pengendalian dan sistem informasi berpengaruh secara signifikan pada kualitas audit.

Dengan pertimbangan tersebut penulis memilih KAP Ispiady \& Dande sebagai studi kasus penelitian ini, karena KAP Ispiady \& Dande merupakan KAP yang baru berdiri pada tahun 2017 dan telah dipercayakan untuk mengaudit laporan keuangan dari perusahaanperusahaan di Korindo Group, dimana Korindo Group memiliki perusahaanperusahaan besar yang terdapat di seluruh wilayah Indonesia. PT. Tunas Timber Lestari adalah salah satu perusahaan dari Korindo Group yang di audit oleh KAP Ispiady \& Dande. Pada proses audit tahun buku 2017 dan 2018, KAP Ispiady \& Dande tidak pernah mendapatkan kembali bukti audit yang diberikan kepada klien, namun auditor tetap memberikan hasil opini "wajar". Salah satu bukti audit yang tidak klien kembalikan kepada auditor seperti konfirmasi pada akun piutang dan pinjaman afiliasi. Hal tersebut dapat menjadi perhatian perusahaan tentang sikap skeptisme auditor terhadap laporan keuangan yang di audit. Dalam dunia akuntan pubik sudah banyak kasus kegagalan auditor yang kedapatan memberikan opini wajar namun tidak dapat memberikan cukup bukti atas transaksi yang di audit. Untuk menghindari hal tersebut, KAP dapat meningkatkan evaluasi pengendalian internal dan menerapkan due professional care dalam melaksanakan tugas audit.

\section{METODE PENELITIAN}

Objek dalam penelitian ini adalah KAP Ispiady \& Dande, adapun alatmat dari kantor KAP Ispiady \& Dande ialah di Jl. Ciputat Raya No. 14 B Lt. 2 Pondok Pinang Kebayoran Lama Jakarta Selatan DKI Jakarta 1230. Penelitian ini dilakukan selama 3 bulan yang diawali dengan peninjauan ke lokasi KAP Ispiady \& Dande pada bulan Maret 2019, kemudian dilanjutkan dengen penyebaran kuesioner kepada staff KAP Ispiady \& Dande selama bulan Maret sampai bulan Mei 2019.

Variabel pada peneltian ini, yaitu variable independen (variabel bebas) berupa pengendalian internal dan due professional care dan variabel dependen (variabel terikat) berupa kualitas audit. Berdasarkan landsan teori dan penelitian terdahulu, maka penulis menguraikannya dalam gambaran kerangka konseptual sebagai berikut :

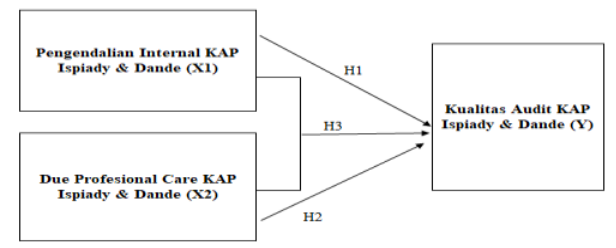

Gambar1. Kerangka Konseptual

\section{HASIL DAN PEMBAHASAN}

Berdasarkan hasil penelitian uji hipotesis yang telah dilakukan sebelumnya oleh peneliti, maka hasil uji hipotesis dapat disimpulkan dalam tabel 1 sebagai berikut:

Tabel 1. Ringkasan Hasil Uji Hipotesis

\begin{tabular}{|c|c|c|c|c|}
\hline \multirow[t]{2}{*}{ Variabel } & \multirow[t]{2}{*}{ Koefisien Regresi } & \multicolumn{2}{|c|}{$\begin{array}{c}\text { Uji Statistik } \\
\mathrm{t}\end{array}$} & \multirow[t]{2}{*}{ Signifikan } \\
\hline & & $\mathrm{t}_{\text {hitumg }}$ & $t_{\text {tabel }}$ & \\
\hline (Constant) & 1,336 & 0,548 & 2,051 & 0,588 \\
\hline Pengendalian Internal (X1) & 0,257 & 7,686 & 2,051 & 0,000 \\
\hline Due Professional Care $(X 2)$ & 0,204 & 3,236 & 2,051 & 0,003 \\
\hline $\begin{array}{ll}\mathrm{F}_{\text {hitung }} & =30,862 \\
\mathrm{~F}_{\text {tabel }} & =3,35 \\
\text { R Square }=0,696 & \\
N & =30\end{array}$ & Sig. $=0,000$ & & & \\
\hline
\end{tabular}

Sumber: Data Primer yang diolah, (2019) 
Berdasarkan tabel di atas didapatkan persamaan regresi adalah : $\mathbf{Y}=\mathbf{1 , 3 3 6}+\mathbf{0 , 2 0 4}$ $\left(\mathbf{x}_{1}\right)+\mathbf{0 , 2 5 7}\left(\mathbf{x}_{2}\right)$, Dari persamaan regresi tersebut didapat kesimpulan sebagai berikut:

Pada koefisien linier berganda terdapat nilai konstanta sebesar 1,336. Artinya apabila variabel pengendalian internal dan due professional care bernilai 0, maka besarnya kualitas audit akan naik sebesar 1,336. Dengan kata lain, jika evaluasi pengendalian internal dan penerapan due professional care pada KAP Ispiady \& Dande dijalankan secara simultan akan berpengaruh terhadap kualitas audit sebesar 1,336.

Pada koefisien linier berganda, variabel pengendalian internal sebesar 0,257. Artinya jika variabel pengendalian internal berubah sebesar satu satuan, maka kualitas audit akan berubah sebesar nilai koefisien regresi variabel tersebut. Hal ini memberikan implikasi praktis, bahwa evaluasi pengendalian internal KAP Ispiady \& Dande memberikan dampak terhadap kualitas audit yang dihasilkan, setiap kenaikan atau penambahan evaluasi pengendalian internal akan menaikan kualitas audit sebesar 0,257.

Pada koefisien regresi linier berganda, variabel due professional care sebesar 0,204. Artinya bila variabel due professional care berubah sebesar satu satuan, maka kualitas audit akan berubah sebesar nilai koefisien regresi variabel tersebut. Hal ini memberikan implikasi praktis, bahwa penerapan due professional care pada KAP Ispiady \& Dande memberikan dampak terhadap penerimaan atas kualitas audit. Peningkatan kualitas audit yang diakibatkan faktor ini adalah sebesar 0,204. Dan apabila dalam pelaksanaan penerapan due professional care tidak ditingkatkan maka kualitas audit akan mengalami kenaikan sebesar koefisien regresi tersebut.

Sedangkan dalam tabel-26 menunjukan hasil uji koefisien daterminasi diatas menunjukan nilai adjusted $\mathrm{R}^{2}$ sebesar 0,696. Hal ini berarti $69,6 \%$ variabel kualitas audit dapat dijelaskan oleh dua variabel independen yang digunakan dalam penelitian ini yang meliputi pengendalian internal dan due professional care. Sedangkan sisanya, yaitu sebesar 30,4\% dijelaskan oleh variabel atau faktor-faktor lain diluar model yang tidak dijelaskan dalam penelitian ini.

Selanjutnya berdasarkan tabel-26 dalam uji simultan (statistikF) menunjukan bahwa nilai $F_{\text {hitung }}$ sebesar 30,862 dengan tingkat siginfikansi 0,000 . Nilai signifikan tersebut lebih kecil dari 0,05 dan nilai $F_{\text {hitung }}$ lebih besar dari $F_{\text {tabel }}$ sebesar 3,35. Sehingga dapat dikatakan bahwa hipotesis diterima, artinya pengendalian Internal dan due professional care secara simultan mempunyai pengaruh yang signifikan terhadap kualitas audit.

Kemudian berdasarkan tabel-26 dalam uji statistik $\mathrm{t}$ menunjukan nilai $\mathrm{t}_{\text {hitung }}$ untuk variabel pengendalian internal sebesar 7.686, dengan tingkat signifikan 0,000 . Sehingga dapat disimpulkan bahwa thitung lebih besar dari $t_{\text {tabel, }}$, yakni $7.686>2,051$ dengan probabilitas signifikan yakni $0,000<0,05$. Dari hasil tersebut dapat dikatakan bahwa Ho diterima, artinya evaluasi pengendalian internal secara parsial terdapat pengaruh yang signifikan terhadap kualitas audit.

Dalam uji statistik t pada tabel-26 juga menunjukan nilai $t_{\text {hitung }}$ untuk variabel due professional care sebesar 3,236, dengan tingkat signifikan 0,003. Sehingga dapat disimpulkan bahwa $t_{\text {hitung }}$ lebih besar dari $t_{\text {tabel }}$ yakni 3,236>2,051 dengan probabilitas signifikan yakni $0,003<0,05$. Dari hasil tersebut dapat dikatakan bahwa $\mathrm{H}_{\mathrm{O}}$ diterima, berarti penerapan due professional care secara parsial terdapat pengaruh yang signifikan terhadap kualitas audit. Berikut ringkasan hasil hipotesis statistik $\mathrm{F}$ dan uji statistik $\mathrm{t}$ dalam tabel sebagai berikut: 
Tabel 2.Ringkasan Hasil Hipotesis Uji statistikF Dan Uji Statistik t

\begin{tabular}{|c|c|c|c|c|}
\hline $\begin{array}{c}\text { Uji } \\
\text { Statisti } \\
\mathbf{k}\end{array}$ & Model & $\begin{array}{c}\text { Hasil } \\
\text { Statisti } \\
\mathbf{k}\end{array}$ & $\begin{array}{c}\text { Hasil } \\
\text { Hipotesi } \\
\text { s }\end{array}$ & $\begin{array}{c}\text { Kesimpula } \\
\mathbf{n}\end{array}$ \\
\hline Uji F & Regression & $\begin{array}{l}30,862 \\
>3,35 \\
0,00< \\
0,05\end{array}$ & $\begin{array}{l}\mathrm{H}_{\mathrm{O}} \\
\text { diterima }\end{array}$ & $\begin{array}{l}\mathrm{H}_{\mathrm{O} \text { : }} \\
\text { Pengendalia } \\
\text { n Internal } \\
\text { dan Due } \\
\text { Professional } \\
\text { Care secara } \\
\text { simultan } \\
\text { mempunyai } \\
\text { pengaruh } \\
\text { yang } \\
\text { signifikan } \\
\text { terhadap } \\
\text { kualitas } \\
\text { audit . }\end{array}$ \\
\hline \multirow[t]{2}{*}{ Uji t } & $\begin{array}{l}\text { Pengendalia } \\
\mathrm{n} \text { Internal } \\
(\mathrm{X} 1)\end{array}$ & $\begin{array}{l}7,686> \\
2,051 \\
0,00< \\
0,05\end{array}$ & $\begin{array}{l}\mathrm{H}_{\mathrm{O}} \\
\text { diterima }\end{array}$ & $\begin{array}{l}\mathrm{H}_{\mathrm{a}} 1 \text { : } \\
\text { Evaluasi } \\
\text { pengendalia } \\
\mathrm{n} \text { internal } \\
\text { secara } \\
\text { parsial } \\
\text { terdapat } \\
\text { pengaruh } \\
\text { yang } \\
\text { signifikan } \\
\text { terhadap } \\
\text { kualitas } \\
\text { audit. }\end{array}$ \\
\hline & $\begin{array}{l}\text { Due } \\
\text { Professional } \\
\text { Care (X2) }\end{array}$ & $\begin{array}{l}3,236 \\
>2,051 \\
0,003< \\
0,05\end{array}$ & $\begin{array}{l}\mathrm{H}_{\mathrm{O}} \\
\text { diterima }\end{array}$ & $\begin{array}{l}\mathrm{H}_{\mathrm{O}} 2 \text { : } \\
\text { Penerapan } \\
\text { due } \\
\text { professional } \\
\text { care secara } \\
\text { parsial } \\
\text { terdapat } \\
\text { pengaruh } \\
\text { yang } \\
\text { signifikan } \\
\text { terhadap } \\
\text { kualitas } \\
\text { audit. }\end{array}$ \\
\hline
\end{tabular}

Sumber: Data Primer yang diolah, (2019)

\section{Pembahasan}

Berdasarkan hasil penelitian yang telah dilakukan oleh peneliti, maka dapat dibuat suatu penjelasan melalui interpretasi dengan membandingkan penlitian terdahulu, adapun interpretasi dalam penelitian ini adalah sebagai berikut:

\section{Hasil Uji Pengaruh Evaluasi Pengendalian Internal Secara Parsial Terhadap Kualitas Audit.}

Hasil penelitian ini menunjukan bahwa evaluasi pengendalian internal secara parsial memiliki pengaruh yang signifikan terhadap kualitas audit, dimana nilai $t_{\text {hitung }}$ lebih besar dari $t_{\text {tabel }}$ yakni 7,868>2,051 dan signifikan sebesar 0,00 lebih kecil dari 0,05. Hal ini berarti bahwa pengendalian internal berjalan lurus dengan kualitas audit yang dihasilkan KAP Ispiady \& Dande untuk perusahaan Korindo Group.

Hasil Penelitian ini sesuai dengan penelitian yang dilaukan oleh Muh. Ichsan Gaffar (2015), dengan judul "Pengaruh Tingkat Pemahaman Pengendalian Internal Terhadap Kualitas Audit" (Studi Empiris Pada Kantor Akuntan Publik Di Makasar). Metode yang digunakan dalam penelitian ini adalah regresi linier berganda. Hasil penelitian tersebut menunjukan bahwa lima indikator penendalian internal memiliki pengaruh positif dan signifikan terhadap kualitas audit. Hal ini dikarenakan auditor dituntut untuk memahami pengendalian internal dalam merencanakan audit, mengevaluasi dan menilai apakah pengendalian tersebut diimplementasikan dengan baik. Semakin baik evaluasi pengendalian internal yang dilakukan maka dapat menghasilkan kualitas audit yang baik juga. Hal ini sesuai dengan teori kognitif dimana auditor dalam melaksanakan tugas audit dipengaruhi denga faktor internal yang ada didalam dirinya yaitu evaluasi pengendalian internal.

\section{Hasil Uji Pengaruh Due Professional Care Secara Parsial Terhadap Kualitas Audit.}

Hasil penelitian ini menunjukan bahwa penerapan due professional care secara parsial tidak memiliki pengaruh yang signifikan terhadap kualitas audit, dimana nilai $t_{\text {hitung }}$ lebih besar dari $t_{\text {tabel }}$ yakni 3,236> 2,051 dan signifikan sebesar 0,003 lebih kecil dari 0,05. Hal ini berarti bahwa indikator due professional care berjalan lurus dengan kualitas audit yang dihasilkan KAP Ispiaday \& Dande untuk perusahaan Korindo Group.

Hasil Penelitian ini sesuai dengan penelitian yang pernah dilaukan oleh Sabella (2017) dengan judul "Pengaruh Due Professional Care, Kompetensi Professional Terhadap Kualitas Audit" (Studi Empiris Ditibjau Dari Sudut Pandang Klien KAP Arsyad \& Rekan). Metode yang digunakan dalam penelitian ini adalah regresi linier berganda. Hasil dalam penelitian tersebut menunjukan bahwa variabel due professional 
care secara parsial memiliki pengaruh terhadap kualitas audit, namun tidak berpengaruh secara signifikan. Auditor KAP Ispiady \& Dande harus menjaga sikap auditor yang cermat dan profesional selama melaksanakan tugas audit. Jika gagal dalam menerapkan sikap auditor yang cermat dan professional, maka opini audit yang dihasilkan tidak berkualitas baik.

\section{Hasil Uji Pengaruh Evaluasi Pengendalian Internal dan Penerapan Due Professional Care secara simultan terhadap Kualitas Audit}

Berdasarkan hasil uji statistik $F$ menunjukan bahwa variabel pengendalian internal dan due professional care secara bersama-sama berpengaruh secara signifikan terhadap kualitas audit dengan nilai $F_{\text {hitung }}$ sebesar 30,862 dan tingkat siginfikan sebesar 0,000 . Nilai signifikan tersebut lebih kecil dari 0,05 dan nilai $F_{\text {hitung }}$ lebih besar dari $F_{\text {tabel }}$ sebesar 3,35. Hal ini dikarenakan bahwa kualitas audit yang baik dapat dipengaruhi oleh tingginya evaluasi pengendalian internal serta didukung secara bersama-sama dengan penerapan due professional care yang dimiliki oleh auditor KAP Ispiady \& Dande.

\section{KESIMPULAN}

Penelitian ini bertujuan untuk mengathui sejauh mana pengaruh evaluasi pengendalian internal dan penerapan due professional care terhadap kualitas audit KAP Ispiady \& Dande, baik secara parsial maupun secara simultan. Berdasarkan data yang telah terkumpul dan telah melewati pengujian terhadap permasalahan dengan menggunakan metode regresi linier berganda, maka dapat disimpulkan sebagai berikut. Berdasarkan hasil uji t, variabel pengendalian internal secara parsial terdapat pengaruh yang signifikan terhadap kualitas audit. Sehingga dapat disimpulkan jika evaluasi pengendalian internal yang dilakukan KAP Ispiady \& Dande tingkatkan maka kualitas audit yang akan diterima oleh perusahaan Korindo Group akan meningkat juga. Hal ini sesuai dengan teori kognitif dimana auditor dalam melaksanakan tugas audit dipengaruhi dengan faktor internal yang ada didalam dirinya yaitu evaluasi pengendalian internal.
Berdasarkan hasil uji t, variabel due professional care secara parsial terdapat pengaruh yang signifikan terhadap kualitas audit. Sehingga dapat disimpulkan bahwa jika penerapan due professional care yang diterapkan oleh KAP Ispiady \& Dande ditingkatkan maka kualitas audit yang akan diterima oleh perusahaan Korindo Group akan meningkat juga. Dengan itu Auditor KAP Ispiady \& Dande harus menjaga sikap auditor yang cermat dan professional selama melaksanakan tugas audit. Jika gagal dalam menerapkan sikap auditor yang cermat dan profesional, maka opini audit yang dihasilkan tidak berkualitas baik.

Berdasarkan hasil uji $F$, evaluasi pengendalian internal dan penerapan due professional care secara bersama-sama memiliki pengaruh dan signifikan terhadap kualitas audit. Sehingga dapat disimpulkan kualias audit yang dihasilkan KAP Ispiady \& Dande untuk perusahaan Korindo Group akan berkualitas baik jika KAP Ispiady \& Dande melaksanakan evaluasi pengendalian internal serta dukungan secara bersama-sama dengan di terapkannya sikap due professional care sebelum melaksanakan tugas audit.

\section{DAFTAR PUSTAKA}

Agoes, Sukrisno, 2017, Auditing, Buku Dua, Edisi Kelima, Jakarta: Salemba Empat

Bungin, Burhandan Mohammed, Rusli, 2015, Audit Komunikasi, Jakarta: Kencana

Arens, A. Alvin, Randal, J. Elder dan Mark, S. Beasley, 2015, Auditing dan Jasa Assurance (Pendekatan Terintegrasi), Edisi Kelima, Jilid Satu, Jakarta: Erlangga.

Azhari, Muqsidina Sabella, 2017, Pengaruh Due Professional Care dan Kompetensi Profesional Terhadap Kualitas Audit (Studi Empiris Ditinjau Dari Sudut Pandang Klien KAP Arsyad \& Rekan), Jakarta: Skripsi Fakultas Ekonomi Universitas Krisnadwipayana.

Desty, AnnisaPupatriani, 2014, Pengaruh Independensi dan Due Professional Care Terhadap Kualitas Audit (Survei pada Kantor Akuntan Publik di Kota Bandung), Bandung: Skripsi Fakultas Ekonomi Univeristas Pasundan 
Halim, Abdul, 2015, Auditing (Dasar-dasar Audit Laporan Keuangan), JilidSatu, Edisi Kelima, Yogyakarta: UPP STIM YKPN

Hery, 2017, Auditing dan Asuransi, Jakarta: Grasindo

Hery, 2015, PengantarAkuntansi, Jakarta: Grasindo

Hery,2014, Kajian Riset Akuntansi (Mengulas Berbagai Hasil Penelitian Terkini Dalam Bidang Akuntansi dan Keuangan), Jakarta: Grasindo

Hery, 2014, Pengandalian Akuntansi dan Manajemen, Edisi Pertama, Jakarta: Kencana

Hery, 2015, Auditing I (Dasar-dasar Pemeriksaan Akuntansi) Cetakan ke tiga, Jakarta: Grasubdo

Junaidi dan Nudiono, 2016, Kualitas Audit (Perspektif Opini Going Concern), Yogyakarta: Andi

Jaya, Indra, 2019, Penerapan Statistika Untuk Penelitian Pendidikan, Jakarta: Prenadamedia

Komang Ayu Tri Handayani \& Lely Aryani Merkusiwati, (2015), Pengaruh Independensi Auditor dan Kompetensi Auditor Pada Skeptisme Professional Auditor dan Implikasinya Terhadap Kualitas Audit, ISSN: 2302-8556 EJurnal Akuntansi Universitas Udayana 101(2015):229-243.

Made Krisna Kusuma Ningrum \& Ketut Budiartha, (2017), Etika Auditor Memoderasi Pengaruh Pengalaman Auditor, Kompetensi dan Due Professional Care Pada Kualitas Audit, ISSN: 2302-8556 E-Jurnal Akuntansi Universitas Udayana Vol.20.1.Juli(2017): 615-644.

Mulyadi, 2014, Auditing, Edisi Enam, Jakarta: Salemba Empat

Mulyadi, 2016, Sistem Akuntansi, Edisi Keempat, Jakarta: Salemba Empat

Muh.Ichsan, Gafar, (2015), Pengaruh Tingkat Pemahaman Pengendalian Internal Terhadap Kualitas Audit (Studi Empiris Pada Kantor Akuntan Publik Di Makasar), Makasar: Skripsi Fakultas Ekonomi dan Bisnis Universitas Hasanuddin Makasar.
Standar Profesional Akuntan Publik (SPAP), 2011, PSA No 04 SA Seksi 230, Jakarta: Institut Akuntan Publik Indonesia

Supriyono, 2018, Akuntansi Keprilakuan, Yogyakarta: Gajah Mada University Press.

Sufren, Yonathan Natanael, 2014, Belajar Otodidak SPSS Pasti Bisa, Jakarta: Komputindo.

Tandiontong, Mathius, 2016, Kualitas Audit dan Pengukurannya, Bandung: Alfabeta

Tuanakotta, Theodorus M, 2015, Audit Kontemporer, Jakarta: Salemba Empat

Panggih, Lutiari Hastama, 2015, Pengaruh Independensi, Pengalaman, Due Professional Care dan Akuntabilitas Terhadap Kualitas Audit (Studi Empiris Pada KAP daerah Istimewa Yogyakarta), Yogyakarta: Skripsi

Wareza, Monica, 2018, Kasus SNP Finance, OJK Harap ada Efek Jera Ke Akuntan Publik, Jakarta; CNBC Indonesia

Yadiati, Wiwin dan Adulloh, 2017, Kualitas Laporan Keuangan (Kajian Teoritis dan Empiris), Jakarta: Kencana

Yazdi, Ali Asgari, 2016, Sejarah Skeptisisme, Jakarta: Sadra International Institute.

Zulfikar, 2016, Pasar Modal Dan Pendekatan Statistika, Yogyakarta: Deepublish. 
ISSN : 2406-7415

e-ISSN : 2655-9919

JURNAL AKUNTANSI DAN BISNIS KRISNADWIPAYANA Vol. 6 No. 3 (September - Desember) 2019

DOI: http://dx.doi.org/10.35137/jabk.v6i3.322 